\title{
IAMJ
}

INTERNATIONAL

AYURVEDIC

MEDICAL JOURNAL

Review Article

ISSN: 2320-5091

Impact Factor: 6.719

\section{UNDERSTANDING OF LIFESTYLE DISEASES IN THE LIGHT OF AYURVEDA}

\section{Rana Shivani ${ }^{1}$, Pathania Deepak ${ }^{2}$}

${ }^{1}$ MD Scholar, Dept. of Swasthavritta, R.G.G.P.G. Ay. College \& Hospital Paprola, District Kangra, Himachal Pradesh, India

${ }^{2}$ MD Scholar, Dept. of Kaumarbhritya, R.G.G.P.G. Ay. College \& Hospital Paprola, District Kangra, Himachal Pradesh, India

Corresponding Author: shivanimona94@gmail.com

\section{https://doi.org/10.46607/iamj2609102021}

(Published Online: October 2021)

Open Access

(C) International Ayurvedic Medical Journal, India 2021

Article Received:24/09//2021 - Peer Reviewed:06/10/2021 - Accepted for Publication:07/10/2021

\section{Check for updates}

\begin{abstract}
Ayurveda is one of the most ancient medical sciences in the world. It is more life and health-oriented and emphasizes prevention rather than cure. In Ayurvedic texts "CHARYA" word has been used to denote lifestyle or day to day activities being performed by individuals. Charya means "Aahara" and "Vihara", which is to be consumed or followed, to maintain Swasthaya (Health) of an individual. A Comprehensive schedule of a health regimen for promotion and preservation of health as a code of conduct which can be attained through Dincharya (Daily regimen), Ratricharya (night regimen), Ritucharya (seasonal regimen), Vyaayaam (exercise), along with AaharaVidhi Vidhana (rules of diet) has been described in Ayurvedic texts. Lifestyle is the way in which a person lives. Lifestyle includes behaviours such as dietary habits, sleeping and resting habits, physical activity (include exercising), weight control, smoking and alcohol consumption. The diseases which are not transmitted by any vector, environment and not transmitted from person to person is called Non-Communicable Disease or chronic disease or Lifestyle disease. In Ayurvedic texts, there is no such type of disease mentioned but in Ayurveda, this kind of disease and its causative factors have been mentioned in abundance during the description of Nidana. So, an attempt has been made to understand the Lifestyle diseases and their Nidanain the light of Ayurveda, through this paper.
\end{abstract}

Keywords: Charya, Vihara, Lifestyle. 


\section{INTRODUCTION}

Ayurveda is an ancient system of medicine which has been originated from "Atharvaveda." It is the science of life and longevity. Ayurveda apart from providing various therapeutic measures for diseases emphasizes maintenance, promotion of health and prevention of diseases through diet and lifestyle regimens. A lifestyle typically reflects an individual's attitudes, way of life and values. Lifestyle is the interests, opinions, behaviours, and behavioural orientations of an individual, group or culture. In Ayurvedic texts " $C H A R$ $Y A$ " word has been used to denote lifestyle or day to day activities being performed by individuals. Charya means "Aahara" and "Vihara" which is to be consumed or followed, to maintain Swasthaya (Health) of an individual.

\section{AIM \& OBJECTIVES}

1. To study the Lifestyle diseases in the light of Ayurveda.

2. To study the Nidana of major Lifestyle diseases (CVD, Obesity, Hypertension, Diabetes mellitus 2) according to Ayurveda.

\section{MATERIAL AND METHODS}

In Ayurveda life is considered as the union of body, senses, mind, and soul. The physical world including the human body is derived from the specific combinations of five fundamental entities i.e., Akasha, $\mathrm{Va}$ yu, Teja, Jala and Prithvi which are known as Panchmahabhuta and soul. Panchmahabhuta forms the Tridosha i.e., Vata, Pitta and Kapha Dosha, Dhatu (tissues) and Mala (excretory products). These carry out physiological activities and are responsible for the integrity of the human body.

Thus, the health of an individual depends on the normalcy of the Dosha, Dhatu and Mala. According to Ayurveda, diseases are caused by wrong "Aahara" \& "Vihara". Due to faulty diet and lifestyle, the normalcy of the Tridoshais disturbed and they vitiate in the body. Vitiated Tridosha disturbs the normalcy of
Dhatu and Mala causing their vitiation which manifests as various diseases in the body.

There are some other causative factors of disease other than unwholesome food. Classically Ayurveda describes three major causes of illness.

Asatmendriyartha Sanyoga (unwholesome conjunction of the sense organs with their object), Pragyaparadha (intellectual blasphemy) and Parinama (transformation) -these are the threefold cause of diseases. Proper utilization of the objects, action and time is beneficial to the maintenance of normal health.

1. Asatmendriyartha Sanyoga: Atiyoga (overuse), Hinayoga (less use) and Mithyayoga (misuse) of sense organs are responsible for the manifestation of many diseases. Overeating is related to the Asamyaka Yoga of Indriya especially "Rasnendriya" The intake of one or two Rasa in high quantity continuously and avoid following the wholesome diet along with its proper methods is the main causative factor of lifestyle diseases.

2. Pragyaparadha: It is the root cause of many diseases. It is entirely applicable in the manifestation of lifestyle diseases. The word Pragyaparadha is made from two words Pragya \& Apradha. Pragya means Buddhi, Dhriti, Smriti and Apradha mean malpractice. When the Buddhi (intellect), Dhriti (restraint) and Smriti(memory)do not carry out their respective functions properly due to their derangement, it causes the occurrence of improper actions (Ashubha Karma). These improper actions cause vitiation of all Dosha and imbalance of Dosha is one of the major causes of illness. (Ch. Sh.1/102) ${ }^{\mathbf{1}}$

The causes of lifestyle diseases are like Pragyaparadha mentioned by Aacharya Charaka in Charaka Samhita which has been described in the table below:(Ch. Sh.1/103-108) ${ }^{2}$ 
Pragyaparadha mentioned in Charaka Samhita

mnhj. kaxfrerkeqnh. kkZuka p fuxzg A

Forceful propulsion of natural urges or their suppression.

deZdkykfrikr'pfe+F; kjEHk'pdeZ.kke A

Excessive or delayed or wrong actions.

KkrkukaLo; eFkkZukefgrkukafu 'kso.ke A

Repeating non-beneficial things knowingly.
Factors that cause Lifestyle diseases

Wrong bowel habits.

Lack of physical activities (Sedentary lifestyle) or over exertion. Lack of sleep, Inadequate sleep, or rest, waking up late, Sitting for long hours in front of computers etc.

Addiction- Smoking, Alcohol, Drug, Artificial sweeteners, Taste enhancers, Preservatives, Artificial flavours, Fast foods, soft drinks etc.
3. Parinama: It refers to Samyaka and AsamyakaYoga of different seasons. It is not directly related to lifestyle diseases.

\section{LIFESTYLE DISEASES:}

There is no such type of disease mentioned in Ayurvedic classics but in Ayurveda, this kind of disease and its causative factors have been mentioned in abundance during the description of Nidana. Lifestyle diseases can be understood and defined in the light of Ayurveda as, "A disease manifested by faulty Aahara and Viharaas Nidana due to not following the rules of Ritucharya along with its Dinacharya \& Ratricharya, having slow \& progressive pathogenesis and Upachaya in nature at various level of the human body may be called as Lifestyle Disease.

All the normal and abnormal events in the body are dependent upon causative factors. For the maintenance of their normal state i.e., positive health, one should resort to such regimens as would be conducive to their normalcy. Similarly, for the cure of diseases that constitute an abnormal state of the body, regimens that are conducive to their abnormality, should be avoided.

\section{NIDANA OF LIFESTYLE DISEASES:}

All the diseases are caused by the aggravation of Dosha. Aggravation occurs due to the intake of unwholesome food and a faulty lifestyle. Unwholesome food does not cause diseases immediately because of certain factors which come in the way of their manifestation. But in the long run intake of unwholesome food mostly causes diseases.

Aaharaja Nidana: Unwholesome Aahara is a main causative factor for Lifestyle diseases. Unwholesome Aahara in terms of Prakriti (Quality), Rashi (Quantity), Desha (Place), Kala (Time) etc. is responsible for diseases. Ayurveda classics describe all these aspects in a scientific and systematic manner which is called "Aahara Vidhi Visheshaytana." It includes Prakriti (Qualitative characteristic of food), Karana (Processing of food), Sanyoga (Combination), Rashi (Quantity), Desha (Habitat), Kala (Time and seasonal variation), Upyoga Sanstha (Classical Ayurvedic rules of diet) and Upyokta (Consumer of food). (Ch. Vi.1/21) ${ }^{3}$

In the present era, people are not following the prescribed rules for preparing, preserving, and eating food. People don't choose nutrients but choose a combination. Nowadays it is a trend to mix various food items or products to relish the taste, resulting in an incompatible combination that leads to harmful effects on the body. Due to busy lifestyles, there is no set pattern of diet, and they consume the food when they get time. All these factors are responsible for Lifestyle diseases. So, lifestyle diseases are more prevalent in the present era.

\section{Examples of Aaharaja Nidana:}

These are a few examples of food items that are commonly used by an individual in excessive quantity and responsible for lifestyle diseases.

Navanna (New grains)- Guru, Snigdha, Abhishyandi. $(\mathrm{Su} . \mathrm{Su} .46 / 51)^{4}$

If taken in excessive quantity, it causes Jatharagnimandya and the formation of Aam takes place. It causes Srotodushti.

Maida and its preparation -Madhura Rasa, Brihaniya. (Bh.Pr.Kr.Va.25)

Madhura Rasa causes aggravation of Kapha Dosha leads to Agnimandya. Hence Aam formation takes place and causes Srotodushti. 
Rajamasha (Cow Pea)-Madhura, Kashaya, Guru. (Bh.Pr.Dh.Va.44) ${ }^{6}$

Excessive intake causes Agnimandya and will form Aam which causes Srotodushti of RasavahaSrotas.

Masha (Black Gram) and its preparationMadhura, Snigdha, Guru, Medakaphakaraka.

$$
\text { (Bh.Pr.Dh.Va.41-42) }{ }^{7}
$$

Excessive intake of Masha increases Kapha and causes Agnimandya, leading to Aam formation and Srotodushti of Rasavaha and MedovahaSrotas.

Aaluka (Potato) and its preparation- Madhura, Guru, Sheeta, Vatakaphakaraka.

$$
\text { (Bh.Pr. Sha. Va. 96-97) }{ }^{8}
$$

Excessive intake of Aaluka causes Agnimandya and the formation of Aam takes place. It causes Srotodushti of Rasavaha and RaktavahaSrotas.

Gramya-Audaka-Aanup Mansa Rasa (Meat soup of domestic, aquatic, and marshy animals); Like meat soup (Pork), Mahishi (Buffalo)- Madhura, Snigdha, Guru, Kaphakaraka.

(Bh.Pr.Ma.Va.1) ${ }^{9}$

If taken frequently and in excessive quantity, it increases Kapha Dosha and Meda in the body, causing Agnimandya and Aam Rasa. Dushti of Rasavaha, Raktavaha and Medovaha Srotas takes place due to Aam formation.

Navamadyapaana (Alcohol)-Guru, Abhishyandi.

$$
\text { (Bh.Pr.Sa.Va.30) })^{10}
$$

It causes Srotodushti, of Rasavaha, Raktavaha, Mansavahaand MedovahaSrotas.

IkshuRasa (Sugarcane Juice etc.)-Guru, Snigdha, Madhura, Kaphavardhaka.

(As.Hr.Su.5/42) ${ }^{11}$

Excessive intake of Ikshu Rasa causes Kaphavriddhi and form Aam Rasa which causes Srotodushti, of RasavahaSrotas.

Navneeta (Butter)-Purana Navneeta is Madhura, Snigdha, Guru, Kaphakarka and Medakaraka.

$$
\text { (Bh.Pr.Na.Va.6) }{ }^{12}
$$

Excessive intake causes Agnimandya and digestion of Navneeta do not take place, Aam formation occurs. It causes Dushti of Rasavaha and MedovahaSrotas.
Apart from these aetiological factors nowadays some common eatables can be grouped under Nidana of these diseases. e.g.

$>$ Bakery products

$>$ Packed food items

$>$ Junk foods

$>$ Processed foods

$>$ Fried and spicy foods etc.

If a person takes Madhura, Snigdhaand Guru Aahara in excessive quantity, Jatharagni and Medodhatvagni Mandya takes place causing Aam and ApakvaMedovriddhi. Also, Madhura, Snigdhaand Guru Aaharawith day sleep cause Shonita Dusti. Both lead to lifestyle diseases like Sthaulya (Obesity), Madhumeha (Diabetes), Raktagata Vata (Hypertension) and Hridroga (CVD).

B. Viharaja Nidana: Faulty lifestyle is another factor responsible for Lifestyle diseases.

Divaswapna (Day Sleep) -It increases KaphaDosha and causes Jatharagnimandya, which leads to Aam formation. Aam Rasa causes Srotodushti of MedovahaSrotas. (Bh.P.Pu.5/216) ${ }^{13}$

Avyayama (Lack of physical exercise)- Cessation of physical exercise may cause Agnimandya and in turn, forms Aam and Kapha. Here Aam is responsible for Srotovarodha of MedovahaSrotas. (Ch.Vi.5/16) $)^{14}$

Swapanasukham (Enjoying the pleasure of excessive sleeping)-It increases the Kapha Dosha \& causes Agnimandya and Aam formation to occur which causes Srotoavarodha.

$$
\text { (As.S.Su.9/52) })^{15}
$$

Bhojanottar Nidra (Sleeping after meals)-If a person is habitual of sleeping after taking a meal, it causes Aam and Kapha formation. It also causes Raktadushti. Aam is responsible for the blockage of microchannels of Raktavaha and Mansavaha Srotas. (Bh. Pr.5/176) ${ }^{16}$

These factors will aggravate the KaphaDosha and cause Jatharagnimandya, Dhatwagnimandyaand will form AamDosha which causes Srotoavarodha and thus lead to Lifestyle diseases.

\section{Manasika Nidana:}


Achintana (Lack of mental exercise)- It aggravates Kapha Dosha and Aam formation takes place, which causes Srotodushti of Medovaha Srotas. (Ch. Su.21/4) $)^{17}$

Shoka, Chinta, Bhaya (Grief, Stress, Fear) - Hridya being seat of Manasika Bhava-Shoka, Chinta, Bhayaleads to Vayu Prakopa. (Ch.Ch.28/16) ${ }^{18}$
Vayu Prakopa (mainly Vyan Vayu) causes an increase in heart rate and cardiac output which results in Raktagata Vata (Hypertension) and Hridroga (CVDs)

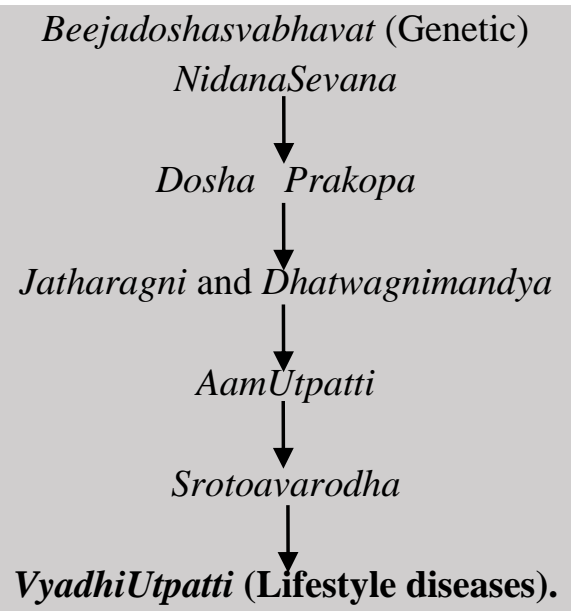

\{Hridroga (CVD), Madhumeha (DM-2), Sthaulya (Obesity) and RaktagataVata (Hypertension)\}

The important principle of Ayurveda, which was put, forwarded by AacharyaCharaka is:

"One causative factor may be responsible for many diseases and a single causative factor may lead to a single disease" 19 . Many causative factors may be responsible for only one disease and many causative factors may lead to many diseases, which is true for lifestyle diseases.

\section{CONCLUSION}

Due to rapid economic development, industrialization, urbanization, globalization \& increasing westernization of lifestyle, India is now suffering from the double burden of diseases i.e., Communicable diseases \&non-communicable diseases. NCDs are associated with faulty lifestyles \& also called "Lifestyle diseases." Due to sedentary lifestyles and faulty dietary habits, people are becoming more susceptible to the lifestyle diseases like Diabetes mellitus, Obesity, Cancer, Chronic respiratory diseases, Stroke, Hypertension etc. In terms of Ayurveda, the diseases which are caused by faulty Aahara and Vihara, having slow \& progressive pathogenesis and Upachaya in nature at various levels of the human body may be called as Lifestyle Disease. A Comprehensive schedule of a health regimen for promotion and preservation of health as code of conduct which can be attained through Dincharya (Daily regimen), Ratricharya (night regimen), Ritucharya (seasonal regimen), Vyaayaam (exercise), along with Aahara VidhiVidhana (rules of diet) have been described in Ayurvedic texts. Hence Lifestyle diseases can be prevented by changing modifiable risk factors or through healthy diet and lifestyle regimens.

\section{REFERENCES}

1. Charak Samhita Of Agnivesha Revised by Charaka and Drdhabala, With Introduction by Vaidya-Samrata Shri Satya Narayana Shastri with Elaborated Vidyotini Hindi Commentary by Pt. Kasinatha Pandeya \& Dr Gorakhanath Chaturvedi, Editorial Board Pt. Rajeswaradatta Shastri, Part-1, Chaukhambha Bharti Academy Varanasi, Reprint -2017, Shareera Sthana 1/102, Page No.824 
2. Charak Samhita Of Agnivesha Revised by Charaka and Drdhabala, With Introduction by Vaidya-Samrata Shri Satya Narayana Shastri with Elaborated Vidyotini Hindi Commentary by Pt. KasinathaPandeya\& Dr Gorakhanath Chaturvedi, Editorial Board Pt. Rajeswaradatta Shastri, Part-1, Chaukhambha Bharti Academy Varanasi, Reprint -2017, ShareeraSthana 1/103-108, Page No.824 - 825

3. Charak Samhita Of Agnivesha Revised by Charaka and Drdhabala, With Introduction by Vaidya-Samrata Shri Satya Narayana Shastri with Elaborated Vidyotini Hindi Commentary by Pt. Kasinatha Pandeya \& Dr Gorakhanath Chaturvedi, Editorial Board Pt. Rajeswaradatta Shastri, Part-1, Chaukhambha Bharti Academy Varanasi, Reprint -2017, Viman Sthana 1/21, Page No.680.

4. Sushruta Samhita Of Maharsi- SusrutabyKavirajaAmbikadutta Shastri, Part-1, Chaukhambha Sanskrit SansthanVaranasi, Reprint-2013, SutraSthan 46/51, Page No.- 246

5. Bhavprakasha Of ShribhavaMisra (Including Bhavprakasha Nighantu Portion) Edited with the 'Vidyotini' Hindi Commentary Notes \& Appendix by Sri BrahmasankaraMisraand Sri Rupalalaji Vaisya First Part, Chaukhambha Sanskrit Bhawan Varanasi, Edition Twelfth, 2018, KritannaVarga- Shloka- 25, Page No.- 875.

6. Bhavprakasha Of ShribhavaMisra (Including Bhavprakasha Nighantu Portion) Edited with the 'Vidyotini' Hindi Commentary Notes \& Appendix by Sri BrahmasankaraMisraand Sri Rupalalaji Vaisya First Part, Chaukhambha Sanskrit Bhawan Varanasi, Edition Twelfth, 2018, DhanyaVarga- Shloka- 44, Page No.- 798

7. Bhavprakasha Of ShribhavaMisra (Including Bhavprakasha Nighantu Portion) Edited with the 'Vidyotini' Hindi Commentary Notes \& Appendix by Sri BrahmasankaraMisraand Sri Rupalalaji Vaisya First Part, Chaukhambha Sanskrit Bhawan Varanasi, Edition Twelfth, 2018, DhanyaVarga- Shloka-41-42, Page No.- 797.

8. Bhavprakasha Of Shribhava Misra (Including Bhavprakasha Nighantu Portion) Edited with the 'Vidyotini' Hindi Commentary Notes \& Appendix by Sri Brahmasankara Misra and Sri Rupalalaji Vaisya First Part, Chaukhambha Sanskrit Bhawan Varanasi, Edition Twelfth, 2018, Shaka Varga- Shloka- 96-97, Page No.- 845.
9. Bhavprakasha Of Shribhava Misra (Including Bhavprakasha Nighantu Portion) Edited with the 'Vidyotini' Hindi Commentary Notes \& Appendix by Sri Brahmasankara Misra and Sri Rupalalaji Vaisya First Part, Chaukhambha Sanskrit Bhawan Varanasi, Edition Twelfth, 2018, Mansa Varga- Shloka- 01, Page No.- 855.

10. Bhavprakasha Of Shribhava Misra (Including Bhavprakasha Nighantu Portion) Edited with the 'Vidyotini' Hindi Commentary Notes \& Appendix by Sri Brahmasankara Misra and Sri Rupalalaji Vaisya First Part, Chaukhambha Sanskrit Bhawan Varanasi, Edition Twelfth, 2018, Sandhana Varga- Shloka- 30, Page No.- 934.

11. Astanga Hridayam of Vagbhatta Edited with the , Vidyotinie Hindi Commentary by Kaviraja Atrideva Gupta Published by Chaukhambha Prakashan Varanasi. Edition: 2017, Sutra Sthana 5/42, Page No. 57.

12. Bhavprakasha Of Shribhava Misra (Including Bhavprakasha Nighantu Portion) Edited with the 'Vidyotini' Hindi Commentary Notes \& Appendix by Sri Brahmasankara Misra and Sri Rupalalaji Vaisya First Part, Chaukhambha Sanskrit Bhawan Varanasi, Edition Twelfth, 2018, Navneeta Varga- Shloka- 06, Page No.- 921.

13. Bhavprakasha Of Shribhava Misra (Including Bhavprakasha Nighantu Portion) Edited with the 'Vidyotini' Hindi Commentary Notes \& Appendix by Sri Brahmasankara Misra and Sri Rupalalaji Vaisya First Part, Chaukhambha Sanskrit Bhawan Varanasi, Edition Twelfth, 2018, Purvardha, Shloka 5/216, Page No.- 140-141.

14. Charak Samhita Of Agnivesha Revised by CharakaandDrdhabala, With Introduction by VaidyaSamrata Shri Satya Narayana Shastri with Elaborated Vidyotini Hindi Commentary by Pt. KasinathaPandeya \& Dr Gorakhanath Chaturvedi, Editorial Board Pt. Rajeswaradatta Shastri, Part-1, Chaukhambha Bharti Academy Varanasi, Reprint -2017, Viman Sthana 5/16, Page No.713.

15. Astanga Samgraha with Hindi Commentary Vol. 1 by Kaviraj Atrideva Gupta Published by Chaukhamba Krishnadas Academy Varanasi. Edition: 2005, Sutra Sthana $9 / 52$.

16. Bhavprakasha Of Shribhava Misra (Including Bhavprakasha Nighantu Portion) Edited with the 'Vidyotini' Hindi Commentary Notes \& Appendix by Sri Brahmasankara Misra and Sri Rupalalaji Vaisya First Part, Chaukhambha Sanskrit Bhawan Varanasi, Edi- 
tion Twelfth, 2018, Purvardha, Shloka 5/176, Page No.- 135.

17. Charak Samhita Of Agnivesha Revised by Charaka and Drdhabala, With Introduction by Vaidya-Samrata Shri Satya Narayana Shastri with Elaborated Vidyotini Hindi Commentary by Pt. KasinathaPandeya \& Dr Gorakhanath Chaturvedi, Editorial Board Pt. Rajeswaradatta Shastri, Part-1, Chaukhambha Bharti Academy Varanasi, Reprint -2017, Sutra Sthana 21/4, Page No.809.

18. Charak Samhita Of Agnivesha Revised by Charakaand Drdhabala, With IntroductionCommentary By Pt. Kasinatha Pandeya \& Dr Gorakhanath Chaturvedi, Editorial Board Pt. Rajeswaradatta Shastri, Part-1, Chaukhambha Bharti Academy Varanasi, Reprint 2017, Chikitsa Sthana 28/16, Page No.779.

19. Charak Samhita Of Agnivesha Revised by Charakaand Drdhabala, With Introduction Commentary by Pt. Kasinatha Pandeya \& Dr Gorakhanath Chaturvedi, Editorial Board Pt. Rajeswaradatta Shastri, Part-1, Chaukhambha Bharti Academy Varanasi, Reprint 2017, NidanaSthana 8/24, Page No.667.

\section{Source of Support: Nil Conflict of Interest: None Declared}

How to cite this URL: Rana Shivani \& Pathania Deepak: Understanding of Lifestyle Diseases in The Light of Ayurveda. International Ayurvedic Medical Journal \{online\} 2021 \{cited October 2021\} Available from: http://www.iamj.in/posts/images/upload/2458 2464.pdf 